\title{
Research on Investor Protection System of Chinese Depositary Receipts
}

\author{
Huang Cao \\ Wuhan University of Technology \\ Wuhan, China
}

\begin{abstract}
In the process of issuing and trading Chinese Depositary Receipts, as with ordinary stocks, there are also acts of false statements by issuer, investor arbitrage and other acts that undermine the order of securities market. In addition to the US securities law and China's securities law, it is necessary to introduce a redemption system to strengthen information disclosure. To ensure the normal issuance and trading of Chinese Depositary Receipts, one is in line with the macro-strategic needs of China's establishment of China Depositary Receipts related systems, and the other is in line with the actual needs of the existing securities market order.
\end{abstract}

Keywords-Chinese Depositary Receipt; Investor protection; Redemption system; Information disclosure

\section{INTRODUCTION}

Chinese Depositary Receipt (CDR) is a certificate issued and traded by other countries' stocks in China. As a curve stock business, the fundamental purpose of issuing depositary receipts by listed companies is to obtain commercial benefits from other countries.

On March 20 this year, the China Securities Regulatory Commission issued the "Several Opinions on Piloting the Issuance of Stocks or Depositary Receipts in Innovative Enterprises". The promulgation of the "Opinions" announced that the CDR is in full swing in the country. On October 12 of the same year, the China Securities Regulatory Commission officially promulgated and implemented the "Regulations on the Implementation of the Interconnection Depositary Receipts Business of the Shanghai Stock Exchange and the London Stock Exchange (Trial)" . On the same day, the Shanghai Stock Exchange formulated supporting business rules in accordance with the regulations to ensure the smooth implementation of the interconnection business between the Shanghai Stock Exchange and the London Stock Exchange, and publicly solicited opinions on the relevant business rules.

Specifically, the depositary receipts are a strong boost for the listing of China's new economic enterprises and China concept shares in China's securities market. Even so, there are still many problems in the establishment of the depositary receipt system in China, whether at the financial level or at the legal level. This article will discuss the protection of Chinese depositary receipt investors on the basis of comparing American law [1].

\section{TRADER PROTECTION SYSTEM FOR AMERICAN DEPOSITARY RECEIPTS}

Depositary receipts, first proposed by the US JP.MORGAN Bank, to circumvent foreign exchange controls in countries such as the United Kingdom. Up to now, the relevant rules of American depositary receipts and its securities legal system have long been famous in the world, and it is also an important paradigm of China's CDR. At present, the depositary receipts in the world are mainly Global Depositary Receipts, American Depositary Receipts and European Depositary Receipts. However, whether it is maturity or acceptability, it is still the first choice for American depositary receipts. Therefore, this paper will discuss the relevant system of Chinese depositary receipts in combination with the investor protection system of American depositary receipts.

There are two basic categories of ADRs: unsecured ADRs and secured ADRs. Unsecured ADR, which is mainly sold by depositary banks, represents the actual shares of foreign companies and does not form formal relations with foreign companies. Often, foreign companies are rarely involved in issuing unsecured ADRs. Conversely, issuers of secured ADRs generally participate actively in the issuance of ADRs and proactively reach an agreement with the depositary bank. Guaranteed ADRs can be further divided into four categories: privately funded ADRs with 144A rules and primary, Level 2 and Level 3 ADRs. The categories vary according to eligible buyers, reporting requirements, ability to raise new capital, and whether securities are listed on the US exchange.

Level 2 and Level 3 ADRs are ADR items traded on the American Stock Exchange, the New York Stock Exchange or the National Securities Dealer Automated Quotation System (NASDAQ). These foreign companies have roughly the same reporting obligations to the US Securities and Exchange Commission and their respective exchanges. The main difference between the secondary and tertiary plans is that secondary ADRs do not issue new shares. As a result, new shares of foreign companies are generally issued through Level 3 ADRs. As the Level 3 ADR program invests more directly in the US securities market, it has more reporting obligations to the US Securities and Exchange Commission [2]. 


\section{A. Reporting and redemption systems}

According to Section 12(a) of the US Securities Act of 1933, all securities registered or listed on US national stock exchanges are subject to registration with the US Securities and Exchange Commission in accordance with the US Securities and Exchange Act. ADR is obviously unavoidable. However, unlike the registration and reporting obligations of ordinary securities, as a special financial arrangement, ADR has a higher reporting obligation, which is to guarantee ADR investors the right to redeem the underlying securities. (the redemption clause: Unless otherwise stipulated by law, when ADR investors require the deposit bank to redeem the underlying securities, the deposit bank must fulfill its redemption obligations.)[3] The creation of redemption rights guarantees the stability of basic securities transactions, and in principle avoids securities fraud and securities misappropriation.

But the redemption rule inevitably leads to the problem of ADR arbitrage. Due to foreign exchange financial factors such as exchange rates, the price of ADR and basic securities are inevitably different. When the ADR price is high, investors will convert the underlying securities into ADRs and sell them on the market to earn the difference; when the underlying securities prices are high, investors can exercise redemption rights and redeem the basis with low-value ADRs. Taiwan Depositary Receipt (TDR) was caused by a large number of investors speculating arbitrage due to loopholes in the conversion rules between TDR and underlying securities, and TDR was forced to withdraw from the market [4].

\section{B. Entrustment information disclosure rules}

Under Section 14(b) of the US Securities and Exchange Act, it is illegal for securities companies, banks, and other institutions that exercise fiduciary rights to violate the Securities and Exchange Commission's rules governing the registration of securities and certain other securities. These other securities are "held for the benefit of investors" , but the securities companies, banks and others are actually entitled to ownership. These issuers, as shareholders listed on the shareholder register, directly enjoy shareholder rights, they abuse voting rights, mix with company property and continue to damage the company's interests. Therefore, the rules for the disclosure of entrustment rights can enhance the general investor's understanding of the company and better supervise the securities company and the depository bank to exercise shareholder rights.

\section{Regulation of false statements}

Section 10(b) of the US Securities Act of 1934(It is illegal for anyone to use any interstate commercial means or facility, mail, or use of any national securities trading facility for any purchase or sale of securities. 1 Use any plans, techniques and strategies Fraudulent; 2 untrue statements or omission of material facts, this material fact is necessary in the circumstances to ensure that the statement is not misleading; 3 engage in any act that may constitute or may constitute fraud Or commercial activities.) prohibits certain acts relating to the purchase or sale of any securities. In particular, it prohibits "any manipulation or deceptive device or facility" and any breach of any securities. These provisions include fraudulent statements and misleading statements of approximate fraud in a reverse list, which can better guide investors' behavior [5].

\section{THE IMPACT OF CDR ON CHINA'S A-SHARES}

Based on transaction security considerations, there are fewer and fewer unsecured ADRs in the United States. In China's financial environment, the guaranteed Level 2 and Level 3 DR models are relatively excellent solutions. The first-level DR can't be listed and traded, and the private-raising DR has strict quantity restrictions, which can't meet the urgent needs of China's securities stock market. Therefore, the introduction of CDR has also put forward higher requirements for relevant domestic financial institutions.

As mentioned in the previous article, China's CDR regulatory regulations are in the process of gradual development and improvement. Various regulations and regulations stipulate the CDR listing conditions, individual investor access qualifications, information disclosure, and transactions and cross-border conversion mechanisms. However, there may still be gaps in some specific aspects. In the basic position of protecting the interests of investors, the ADR can be referred to in the design of legal supervision. Then, based on the supervision system of American depositary receipts, I'll puts forward some suggestions on the legal system design of CDR.

\section{CONSTRUCTION OF ChInA DEPOSITARY RECEIPT INVESTOR PROTECTION SYSTEM}

Chinese depositary receipts are tantamount to a double-edged sword for A-shares. The advantages of CDR need not be described: for domestic, high-quality new Internet technology innovation companies can be listed directly in China, no need to pay more attention to listing overseas, and then achieve the purpose of stimulating the real economy, improving the overall quality of A shares, and rectifying the downturn. For overseas, the listed stocks can be returned to A shares through this form, without having to pay attention to the VIE structure and different voting rights. It is easy to overlook that the CDR has the advantage of rectifying the quality of A shares. At present, there are still quite a few low-performance companies in the A-share market. At the same time, the system design of China's delisting mechanism makes it difficult to realize the delisting, and the review system (quantity limit and long term) of stock listing has caused many high-quality enterprises to be rejected. Therefore, the listing of backdoors has become a helpless move for high-quality companies to list A shares. At the same time, low-performance companies can still occupy a place in A-shares based on their shell resources, even if they do not meet the standards for stock listing and issuance. However, as mentioned above, the introduction of CDRs makes high-quality enterprises not entangled in the indulgence of the audit system, which in turn distorts the value of shell resources, so that low-performance companies no longer enjoy unrealistically high stock prices, and will naturally be marketed. Abandon with investors [6]. 


\section{A. CDR Redemption systems}

Needless to say, as far as the reporting system is concerned, China as a representative of the stock merit regulation, even if the general securities of the listed A-share market still need to accept a series of audits by the CSRC, let alone the depositary receipts that separate the underlying securities from the actual trading securities. The listing of ADR needs to be registered and reported to the US Securities Regulatory Commission. Similarly, the CDR is directly responsible to and supervised by the China Securities Regulatory Commission. Regarding the issue of CDR redemption, the basic redemption right of domestic general investors is a powerful ways to protect their rights. However, in terms of the maturity of the domestic market, it is too harsh to directly require the depository bank to perform the redemption obligation unconditionally. Even in the United States, where the full redemption system is implemented, the arbitrary exercise of the redemption right by investors to take advantage of the price difference seriously disrupts the order of the securities market. It can be seen that the complete copying of the US redemption system is unreasonable and does not conform to the market conditions of the Chinese market. For CDR, we first need to stand on the protection of investors and prevent abuse of investor rights. Thus, the rule that can be tried is to set a period limit for redemption rights. The specific connotation of this restriction is twofold:

First, set the redemption limit period. The redemption right may not be exercised during the statutory period after the holder purchases the CDR, except for other illegal acts such as fraudulent misrepresentation by the issuer of the depositary receipt and the intermediary. The redemption restriction period is based on the legal basis of the short-term trading of China's Securities Law. The short-term trading of CDRs and the short-term transactions of listed company shareholders are similar in the sense of illegal profits. What they both have in common is to regulate the right of rights holders to buy and sell securities in a short period of time. The difference is that the relationship between the holder of the CDR and the overseas issuing company of the underlying securities is not the relationship between the shareholders and the company. Therefore, the short-term trading rights that can be applied to the directors' supervisors are not applicable at certificate holder and the issuer of the depositary receipts. However, when the depositary certificate issuer, intermediary, and other entities issue CDRs in the form of fraud or misrepresentation, the redemption right acts, as a direct way to protect the legitimate rights and interests of investors, from the perspective of interest measurement and the level of legal interest, should reason to break through the redemption period limit.

Second, the expansion of information disclosure obligations. The holder of the depositary receipt shall continue to perform the disclosure obligation for a period of time after the exercise of the redemption right. During the extension of the disclosure obligation, although the holder of the depositary certificate cannot be fully ruled to abuse the redemption right, but the holder of the depositary receipt must disclose the major transaction after the redemption. In general, if there is a malicious arbitrage behavior, such as the price of the underlying security is higher than the price of the depositary receipt due to the change of the market exchange rate, the holder of the depositary receipt will exercise the redemption right and sell the underlying securities again at a high price, etc., China Securities Regulatory Commission will be corresponding penalties for intervention to punish investors for using regulatory loopholes to arbitrarily interfere with the CDR market order.

\section{B. CDR False statement regulations}

In the case of fraudulent disclosure and regulation of misrepresentation, ADR's legal supervision prohibits all actions attributed to or likely to be attributed to fraud or misrepresentation in a one-size-fits-all manner. China's "Securities Law", related securities regulations and the principle of imputation on the determination of false statements, also has a complete system. However, due to the particularity of the structure of the depositary receipts, the legal subject of the depositary receipts generally includes a large number of entities such as a basic securities issuing company, a national memory bank, a foreign custodian bank, a domestic underwriter, and domestic investors and other intermediaries. It is necessary to make a distinction between the principle of imputation of the parties involved in the issuance of depositary receipts and the transaction process.

First, the issuer of the CDR. The legislative practice of securities laws in various countries generally restricts the depositary issuer of securities with no fault liability, because of the depositary issuer participates in the most direct correlation of the issue, and their predictability of disclosure of information risks and the position of protection of investors' interests. Of course, some scholars believe that the national memory trustee should apply the principle of fault.[7]The viewpoint regards the foreign basic securities company as the issuer in the entire CDR issuance process, and only identifies the domestic depositary as the proxy trustee under the depository agreement. The depositary is indeed able to issue CDRs in the domestic agency based on the depositary agreement, but the design of the responsibility of the legal subject cannot be based solely on academic points or foreign practice doctrines, but also on the actual national conditions of China's financial market. In fact, due to financial security considerations, China still adopts a restrictive attitude toward currency exchange under foreign exchange capital projects. Therefore, foreign capital markets still have certain obstacles to the output of the domestic market from the source. At the same time, foreign issuers are far less familiar with the domestic market than their national reputation. The impact of these issuers on the domestic market and investors is very limited, even if they are false statements, it is difficult to influence the domestic market. False statements made by the national memory trustees who directly participate in all aspects of the CDR operation will cause more serious damage to the interests of the depositary certificate holders. Therefore, the issuer of the national memory certificate needs to have the same or more stringent liability limits as the foreign issuer.

Second, custodian banks, CDR underwriters, and other intermediaries. The principle of compensation liability of the above-mentioned responsible subject matter refers to the provisions of Article 69 of the Securities Law. The analogy of 
the issuer's supervisor, the sponsor underwriter and the securities service institution shall apply the fault presumption. Similar to general securities information disclosure, the above-mentioned entities are more responsible for the information disclosure. As an institution that accepts the information disclosed by the listed company, it has the conditions to correct or maintain the false information before the guarantee is underwritten. Therefore, these responsible entities bear indirect responsibility in the securities issuance and information disclosure, so it is necessary to reinforce the weak position of the general investors by inverting the burden of proof.

Finally, the depositary certificate holder or called the investor. The rights of the two are generally the same, but there are differences in the narrow obligations. The most obvious point is that in the provisions of the Securities Law, the liability caused by illegal acts such as false statements mostly ends in the issuer of the listed company and the underwriting sponsor institution, and there are few restrictions on the rights and compensation of the general investor. The holders of depositary receipts are different, in order to protect the early operation of the new securities tools - China Depositary Receipts. As the special trading entities, holders require certain market entry criteria. In the early days of the CDR, relatively strong investors were needed to join, one was to expand the scale of funds for the early CDRs, and the other was to have stronger risk response capabilities of these investors. In addition, as mentioned in the previous article, CDR domestic holders have corresponding legal obligations in information disclosure to regulate investor arbitrage. Therefore, it is relatively reasonable to limit the holder by lowering the degree of responsibility of the CDR issuer and the underwriter, that is, the fault liability.(only when the holder's information disclosure is faulty, can be required to bear certain legal responsibility)

\section{CONCLUSION}

Since 2016, the bottom of the circuit breaker has been broken, and the margin financing funds have fled on a large scale. The market has stepped up the pace of adjustment, and the phenomenon of strong stocks crashing is more serious. Recently, negative news has emerged. The US dollar has risen sharply, crude oil has plummeted, and European and American stock markets have adjusted their expectations [8]. Both of them have had a negative impact on A-shares. The Shanghai Composite Index continued to be sluggish. In this negative stock market environment, it is understandable that the country has introduced Chinese depositary receipts as a means of saving the market. However, as the first financial instrument appearing in China's financial market, CDR needs to further fill the gap in its administrative supervision and judicial enforcement. How to protect the interests of general investors more comprehensively becomes the first issue that should be considered in China's corresponding legal system. From the perspective of redemption system and information disclosure, step by step to improve the legal norms of China's depositary receipt securities is conducive to further standardizing China's securities market and enhancing stock investor confidence. Only on the basis of guaranteeing the interests of ordinary investors can we truly play the role of depositary receipts to activate China's A-shares.

\section{REFERENCES}

[1] Stijn Claessens. The Emergence of Equity Investment in Developing Countries: Overview.[J].The World Bank Economic Review, VOL. 9, NO. 1:,Pages 1-17.

[2] M.Humayun.Kabir,M.Kabir.Hassan,Neal.Maroney International Diversification with American Depository Receipts (ADRs).[J]. Pacific-Basin Finance Journal. Volume 19, Issue 1, January 2011, Pages 98-114.

[3] Sun huijuan. Research on Legal Issues of American Depositary Receipts.[D]. Dalian: Dalian Maritime University.2011. (In Chinese)

[4] Sun dongmeng, Tan xiaofen. Chinese Depositary Receipt (CDR):Evolution, experience and potential impact.[J].International Finance.Volume2018-8,Pages 23-29. (In Chinese)

[5] Vincent M. Chiappini. How American Are American Depositary Receipts? ADRs Rule 10B-5 Suits, and Morrison v.National Australia Bank.[J]. Boston College Law Review. Volume 52.Article 5. Pages 1795-1832.

[6] Zhao xiaolong. Impact of China Depositary Receipt (CDR) on China A-Shares.[J].Financial finance. Volume 2018.09. Pages 200-201. (In Chinese)

[7] Xie guichun. Comparative Study on the Protection Mechanism of Depositary Receipt Holders.[N]. Securities Market Herald. Volume 2018.07.Pages 4-10. (In Chinese)

[8] Jia guoqiang. Unicorn Enterprise Returns to A Shares.[N].China Economic Weekly. Volume 2018.4.9.Pages 17-24. (In Chinese) 